\title{
Accidental Humor in Consecutive Interpreting: Accidentally Useful Food for Thought
}

\author{
Nihal YETKIN-KARAKOÇ ${ }^{1}$
}

Assoc. Prof., Izmir University of Economics, Faculty of Arts and Sciences, English Translation and Interpreting Department, Izmir, Turkey

ORCID: N.Y.K. 0000-0002-7649-5949

\section{Corresponding author:} Nihal YETKIN-KARAKOÇ, İzmir Ekonomi Üniversitesi, Fen-Edebiyat Fakültesi, İng. Mütercim ve Tercümanlık Bölümü, Sakarya Cad. No:156, 35330 İzmir, Türkiye

E-mail: nihal.yetkin@ieu.edu.tr

Submitted: 26.02 .2021

Revision Requested: 04.05.2021

Last Revision Received: 16.05.2021

Accepted: 27.07.2021

Citation: Yetkin-Karakoc, N. (2021). Accidental humor in consecutive interpreting: accidentally useful food for thought. Litera, 31(2), 783-810. https://doi.org/10.26650/LITERA2021-887195

\begin{abstract}
Unlike humor translation, humor in translation, caused by translation errors, is underresearched in translation studies. Accidental humor, as a subgroup of humor, has been analyzed in translation contexts, but to the best knowledge of the author, not in the interpreting context. This descriptive study, being the first of its kind dealing with the accidental humor in consecutive interpreting, is intended to fill the gap in the verbal manifestations of resources in the English-Turkish interpreting context along with the possible reasons for resources of accidental humor in consecutive interpreting class. As a result of the study, a total of 38 accidentally humorous instances are found. The verbal resources are analyzed and divided into main and sub-categories, and for each, examples from the corpus are discussed. In addition, new linguistic resources were discovered, which may be exclusive to this context. The detected items are by no means meant to be exhaustive, as also stated by the former studies, but nevertheless enables greater understanding about the types and possible causes of accidental humor which may occur during the consecutive interpreting process. Given the dearth of literature on accidental humor in consecutive interpreting, this study may provide some insight for remedial teaching/learning in interpreting studies, as well as linguistics. Future studies may examine, among the others, verbal resources in the simultaneous interpreting context and compare the verbal resources in depth in consecutive with those in simultaneous interpreting.
\end{abstract}

Keywords: Accidental humor, consecutive interpreting, humor, humor in translation, verbal resources 


\section{Introduction}

As a universal phenomenon, humor, in a broad sense, can be considered a "multicolored kaleidoscope of thoughts and feelings, times and places" (MacHovec, 2012, p. 20). Due to its intricate nature, it is difficult to encapsulate in a single theory. The theories of humor are generally seen from three theoretical views: incongruity theories, relief theories and superiority theories. These three views complement each other, and together, are able to explain all aspects of humor (Morreall, 1983, p. 10).

The incongruity theory's roots are traceable to Aristotle's arguments, but was developed by Kant (1790) who considered the essence of humor to be the evaporated expectation as stated in Rishel (2002), and also by Schopenhauer (1966), who regarded it as a discrepancy between the "individual perceptions and conceptual abstractions", as cited in Straus (2014, p. 34). The "necessary and sufficient conditions for verbal humor" are identified in Semantic Script Theory of Humor (SSTH) by Raskin (1985). Accordingly, a text is funny in the fulfillment of the following two conditions: "i) the text is compatible, fully or in part, with two different scripts, ii) the two scripts, with which the text is compatible are opposite in a special sense" (1985, p. 99). In a funny text, he states, one may see binary oppositions in three types, namely, "normal/abnormal, actual/nonactual, and possible/impossible." However, as Nijholt (2015) highlighted, not all opposing scripts are humorous, they sometimes may be surprising or confusing because of the incongruity resulting from the opposing scripts, leading to surprise, violation of expectations, ambiguity, assessment of new information, or (re)interpretation of a particular situation/event. SSTH was later extended in General Theory of Verbal Humor (GTVH) by Attardo and Raskin (1991) by adding five knowledge resources, namely, language, narrative strategy, target, situation and logical mechanism. in addition to script opposition, previously specified in Raskin's SSTH (1985).

Relief and Superiority theories account for the roles when experiencing humor. According to Relief or Release theory, one may feel relief of tension through humor; Freud (1960 in Morreall 1983) stated, that laughter is regarded as the outlet of sexual/ aggressive energy repressed However, risus purus, in the words of Beckett (1953, p. 37), is not related to unhappiness, instead an "elevation and liberation, the lucidity of consolation" (Critchley, 2002, p. 111). According to the superiority theory, one may feel superior to the victim of a joke, as one enjoys "seeing others ridiculed" in the words of Zillman and Stocking (1976, p. 154). Seen from this perspective, it is the emotional 
reward in return for discovering and resultantly undoing thought mistakes (Hurley, as stated in Sabato, 2019).

There are three types of humor: accidental, silliness/clowning and directed/targeted (Bainum, Lounsleury, \& Pollio, 1984). Accidental humor, as coined by Nilsen \& Nilsen (2000), in other words, involuntary humor, coined by Bucaria (2004) is distinguished from the other two in terms of intentionality. In the former one, the producer does not have intention to amuse, unlike in the latter. The accidental humor, thus, occurs unintentionally, due to the non-bona fide mode of communication. The immediate consequence does not change, although people are amused (Farghal, 2006). It is worth remembering that humor may result in laughter, but not all laughter results from humor (Ruch, Platt, Proyer, \& Chen, 2019).

In pragmatic terms, intentional and unintentional humor differ. On the one hand, the humorous script in intentional humor usually stems from the producer's flouting the maxims of conversation (Grice, 1975) for a communicative aim (as stated in Farghal, 2006). The essential components of such humor are playful use of language, in the words of Raphaelson-West, "playing with illusions" (1989, p. 140) and having the other person(s) for the enjoyment (Freud, 2003, pp. 186-187). On the other hand, accidental humor results from the unintentional infringement of one or more of the maxims of conversation by the producer (Farghal, 2006).

Seen from the view of interactional humor, intentional humor can be understood in terms of hyperunderstanding, which derives from "a speaker's ability to exploit potential weak spots (ambiguity) in a previous speaker's utterance by echoing the latter's words with a fundamentally different reading", whereas unintentional humor originates from “a genuine misinterpretation of a previous utterance" (Brône, 2008, p. 2028).

Irrespective of the type, humor has many functions. To start with, humor evokes amusement, even if not necessarily laughter. It can thus provide a common ground in a group (Pavlicek \& Pöchhacker, 2002). However, it can also provoke exclusion of some groups (Stephenson, 1951), as well as provide camouflage for derogatory comments (Holmes \& Marra, 2006, p. 124). From a pedagogical perspective, physiologically, it can assist learning through improved respiration and circulation (Garner, 2004). Cognitively, it can illustrate and reinforce already acquired cultural and linguistic knowledge (Deneire, 1995; Askildson, 2005), reduce anxiety and stress (Consalvo, 1989), increase mental 
sharpness (Cousins, 1991), soften an instruction/criticism (Ross, 1992), and contribute to creative thinking in learning (Ziv, 1988).

To the best knowledge of the author, no study has been conducted on accidental humor in the interpreting context. This descriptive research focuses on accidental humor in consecutive interpreting classes. In what follows, a literature review on accidental humor will be given, followed by the discussion of the findings obtained from trainee interpreters relevant to this study.

\section{Accidental humor in translation and interpreting studies literature}

Accidental humor can arise from comic situations, and errors in automatic and human translation. It essentially evolves, just like intentional humor, "from script opposition/ overlap" (Raskin, 1985, as cited in Al-Kharabsheh, 2018, p. 1). In the literature, there are studies on accidental humor in automatic/ machine translation (Nijholt, 2015; Shah \& Warwick, 2016) and human translation in public notices (Farghal, 2006; Al-Kharabsheh, 2008; Macharia, 2019), in pragmatic failures in the Nigerian interlingual communication context (Agbedo \& Krisagbedo, 2014), in puns (Ibraheem \& Abbas, 2016a), in plays (Ibraheem \& Abbas, 2016b) and in humor websites (Ageli, 2014), among others.

There are numerous studies on accidental humor translation. The different verbal resources, analyzed in the literature regarding accidental humor in translation are as follows: Ambiguity, semantic overlap, lexical gap, morpho-phonological similarity, spoonerism and grammar including reference, word order and modality (Farghal, 2006), misspelling, semantic accuracy, semi-translation and denormalizing normality (AlKharabsheh, 2008), mispronunciation, transliteration, ideational somersault (Agbedo \& Crisagbedo, 2014), tautology, coherence (punctuation-related), lisping, paradox and irony (Macharia, 2019).

On the other hand, in the interpreting context, humor in general has seen negligible interest. Very few studies focused on the intentional humor in simultaneous/conference interpreting literature (among the others, Pöchhacker, 1993; Viaggio, 1996; Pavlicek \& Pöchhacker, 2002; Vymětalová, 2017), and none, intentional/ unintentional humor in consecutive interpreting. This study, being the first of its kind dealing with the accidental humor in consecutive interpreting, is intended to fill the gap in the verbal manifestations of resources in the English-Turkish interpreting context. 


\section{Aim and Method of the study}

This descriptive study, being the first of its kind dealing with the accidental humor in consecutive interpreting, is intended to fill the gap in the verbal manifestations of resources in the English-Turkish interpreting context along with the possible reasons for resources of accidental humor in consecutive interpreting class.

The verbal resources were collected retrospectively from the PANOPTO and studentinitiated recordings for in-class activities, quizzes/midterm and final exams of undergraduates aged between 20-22, taken during and for consecutive interpreting classes I and II at a private university. Accordingly, the first data was collected from the conventional laboratory setting, beginning of the semester until 15 March 2020, and then in the pandemic period, the data was collected online from 15 March 2020 to 9 February 2021, the date of the final exam. Written Consent was given by 8 of 11 students in the Consecutive Interpreting II (2019-2020 spring semester) and 31 of 43 students in the course of Consecutive Interpreting I (2020- 2021 fall semester). As part of purposive sampling, only those humorous utterances/incidents which caused verbal humor were chosen and analyzed.

To keep the complexity of texts balanced, the recordings of in-class activities of the Consecutive Interpreting II, being a more advanced group, were excluded, and only three recordings, were common in both courses. Each week, during in-class activities, students were asked to interpret pieces from different texts in different fields (Psychology, Sociology, Philosophy, Archeology, Literature, Ecology, Public Health etc.), prepared one week in advance by their peers as weekly assignment. In the preparation process, they were free to choose any topic under the given scientific field, and requested to prepare introductory, informative texts with a maximum length of 10 sentences in that specific field. As it was not an empirical study, no further limitations were set regarding the text content. For mid-term and final exams, they were faced only with topics and contexts that they became familiarized during the classes. They were given due instruction on the exam topic two weeks earlier before the exam, after which they were allowed to make readings and prepare a glossary which they could use during the exam. The exam text length varied between 10 and 15 sentences of two lines at most, and the duration of the listening and the concurrent note-taking took one minute and a half at most. In addition, they were allowed to listen to the source text twice, considering exam-related psychological constraints such as stress and time pressure. A total of 
three minutes were added for listening to the recording for possible technical issues. Whether the text was used for in-class-activities or the exam, a formal/academic tone was kept. No manipulations were made on texts, which might trigger the occurrence of any accidental humor during the interpreting process.

Except for a few instances (only 6 in number in our corpus), the majority were found in voice recordings sent as assignments/exams to the students on Blackboard Learn, under the assignment slot for consecutive interpreting within a time limit. The chosen examples reflect the exact wording of students. For confidentiality reasons, the examples were given anonymously.

Linguistic resources were found in interpreting classes in the last two semesters. They were identified through accidentally humorous instances. Firstly, verbal resources were analyzed, some categories of which were reported in the literature (ambiguity, semantic overlap, redundancy, reference, morphophonological similarity, spoonerism and grammar). These verbal phenomena were grouped under more general linguistic labels, e.g., lexical, syntactic, phonological etc. Other subgroups were included as new categories, such as collocational confusion, numerical confusion, and confusion of language to be interpreted. At this point, it should also be emphasized that one humorous utterance may yield more than one language resource, given the complex nature of humor itself. The study adopts a qualitative approach and does not provide one with statistics, other than some implications suggested by the low frequency of occurrences.

In what follows, categories and subcategories of instances of verbal accidental humor, are listed, along with the exemplary instances found in the study. The whole list of instances is submitted in the Appendix. The examples start with the original utterance, along with the explanatory comment in parenthesis, added by the author, if necessary. These are followed by the Turkish interpretation, along with the intended reference in parenthesis, added by the author (or omitted as redundant in interpretation for reasons exclusive to Turkish). In most cases, the interpreted excerpts are followed by back translation, for ease of intelligibility, but not in all, because not every incident could be understood with back translation, e.g., homonyms do not coincide across languages. One can also see details such as the setting (whether it happened during face-to-face/on-line class setting or during on-line exams), and the relevant frequency of occurrence. The analysis of the instances examines their origins in terms of linguistics and interpretation didactics. 


\section{Findings}

Verbal accidental humor resources

-Lexical:

Lexical items confused are known to be in the same word class. They are analyzed here under lexical ambiguity, semantic overlap, collocational confusion and redundancy.

Lexical ambiguity: Ambiguity arises from multiple interpretations of a word "with more than one possible meaning in a context" (Oaks, 1994, p. 378). Ambiguity-related accidental humor may arise from polysemy, homonymy, and homophony.

(1) Just before he was six, his father took Mozart to Munich to play at the court. Daha 6 yaşına gelmeden babası mahkemede çalması için onu Münih'e götürdü. (Back translation (BT) makes no contribution to understanding for this category.)

In (1), the underlined word changes sentential meaning depending on its different interpretation, due to its homonymous nature. The humorous interpretation relies on the meaning of word court as a place (such as a chamber) for the administration of justice (Merriam-Webster online, 2021). Actually, in this context, its meaning is the residence or establishment of a sovereign or similar dignitary. As the student reported later, s/he interpreted it according to the familiar meaning, which is mahkeme, an institution where the suits are filed, and in a humorous interpretation, Mozart played music at trials of criminals, settings typically known for their serious atmosphere.

Semantic overlap: Humor can result from the interlocutor's inability to understandsemantically overlapped words (Farghal, 2006). Example (2) provides a humorous example of a momentary confusion of co-hyponyms, in this case virus and sneeze, as a result of which, the sneeze manages to enter the body, according to the interpretation.

(2) All it takes is one sneeze for a virus to get into your body. Bir hapşuruk vücudunuza girdiğinde bağışıklık sisteminiz bundan etkilenir. (BT: When one sneeze gets into your body, your immune system is affected from it.) 
Collocational confusion: Found as a new category, this may arise out of inefficient note-taking in collocational terms, and trying to find an appropriate collocation based on context through instant inferences in the interpreting process.

(3) We can cut the world's yearly carbon emissions by a third. Ağaçları kesmemiz karbon emilimini hızlandırır. (BT: Our cutting the trees accelerates the carbon absorption.)

There are two collocational confusion-related mistakes here. The first one is cutting the trees. The noting of the word "cut" led the student to jump to a hasty conclusion that it referred to trees, though these are not mentioned in the original text. The second is carbon absorption, which appeared in the interpretation, when carbon emission, i.e. the opposite, was the intended meaning. So, what is heard is the humorous interpretation that cutting trees lead to faster carbon absorption, as if trees themselves threaten climate change, contrary to the reality. The confusion of emission and absorption also account for semantic overlap specified above.

Redundancy due to literal interpretation in TL: What is normal and natural in word or phrase may not be so in any other language. The literal translation/interpretation confuses, rather than revealing, the meaning as seen in the following example:

(4) New innovations are making important strides possible, and more are on the way. Yeni yenilikler imkansızı gerçek kılıyor, ve daha fazlası da yolda, geliyor. (BT makes no contribution to understanding for this category.)

In the example (4), new innovations are an established collocation in English but yeni to modify yenilik is redundant and is never used in standard Turkish, as the word itself embraces concept of 'new'. In Turkish, the phrase yeni yenilikler sounds absurd and humorous, as 'old innovation' is a contradiction in terms, according to the Turkish way of thinking; we rather use son yenilikler (the latest, the most recent), instead of yeni yenilikler in such an adjectival phrase.

-Morpho-phonological (malapropism):

In some cases, incidental humor is produced in case of a incorrect use of a lexeme that resembles the target word morpho-phonologically (Farghal, 2006). It can manifest itself in the form of heterographs, with different spelling, or homographs, with same spelling. 
The morpho-phonological similarity may arise from a mispronunciation in the source utterance, and the resulting misinterpretation is given in the following example:

(5) How you treat people is important in interpersonal communication. The word treat here was pronounced as threat, because a student interpreted as follows: Insanları nasıl tehdit ettiğiniz kişilerarası iletişimde önemlidir. (BT: How you threaten people is important in interpersonal communication.)

In (5) there was a confusion between "treat" "to behave", and "threat" "a statement of an intention to inflict pain, injury, damage, or other hostile action on someone in retribution for something done or not done" and the student later reported to have failed to edit it when interpreting, due to lack of awareness at that time.

Sometimes, though there is no mispronunciation in the source utterance, the morphophonological similarity between words may lead the interpreting trainees to a hasty lexical decision, which may turn out to have a tenuous connection with the word in the source text. In such cases, a similarity in form/sound, i.e. even a few syllables, or vowels/consonants with another word would suffice to make such a humorous interpretation, as seen in the example below:

(6) The main regulator of circa diem can be found in hypothalamus, a small area at the base of your brain. Sirkadiyen döngünün ana regülatörü beynin arkasında bulunur, tıpkı hipopotamlardaki gibi.(BT: The main regulator of circa diem is found at the base of your brain, like in hypothalamus'.)

Apparently, in (6), hypothalamus, a part of the brain, was unfamiliar to the trainee, and word was modeled on hippopotamus, a mammal, the image of which caused a humorous interpretation.

-Phonological:

Sound related confusion cannot be necessarily considered to arise from linguistic incompetence, but may be mere slips. A resemblance in the sound, combined with a lapse in concentration may play a role in their occurrence. 
Interlingual homograph: It appears when "words in different languages share the same orthographic form" (Dijkstra, Grainger, \& van Heuven, 1999, p. 497). This was found as a new category in the study.

(7) Sembolizm akımının etkileri şiir ve romanda görüldü. The influences of the symbolism movement were seen in poem and roman (pronounced as in the Roman Empire- /'rəzmən/) (BT) makes no contribution to understanding for this category.)

While the listeners were expecting the word novel as the English rendering of roman, they heard Roman, which evoked a sudden amusement, confirmed by amused comments. The words roman, meaning novel in English translation, and Roman, meaning "of Rome" in English, are the same in form but the meanings are unrelated. This orthographic form overlap resulted in a confused linguistic decision, during interpreting from notes.

Interlingual homophone: "Items with similar pronunciations across languages are called interlingual homophones" (Lemhöfer \& Dijkstra, 2004, p. 533).

(8) More (innovations) are on the way. We will take a shared sense of urgency from countries, companies, cities and all of us working together. Dünyamızı yeniliklere açmak gelecekte birazcık acil durum niyetine girecek. Ülkelerden, şirketlerden, sitelerden bunu bekliyor, birbirimizle beraber çalışmamızı bekliyor. (BT: to open our world to innovations will sort of become emergency. It (The world) expects the countries, companies and sites to work together.)

In the example (8), cities were interpreted as siteler due to a confused linguistic decision. This word is used in Turkish as apartment blocks which share a common management for cleaning, maintenance and so on. The humor of the interpretation comes from the very substantial role humble "apartment blocks" gained in city planning.

Spoonerism: This error occurs "when one sound unit in one word switches with a sound unit in the other word" (Sellers, 2018, p. 2).

(9) Bu akımın temsilcileri arasında Yahya Kemal veTevfik Fikret vardır.-The representative of this movement include Yahya Kemal and Tevfit Fitret. (BT) makes no contribution to understanding for this category.) 
The unintentional transposition of $t$ and $k$ sounds in Tevfik Fikret in (9) is attributable to repetition of these consonants.

Syllable omission: This may arise from a difficulty in pronunciation, especially when some sounds are repeated in the same word, posing a phonological challenge. This was found as a new category in the study.

(10) Germany generates $27 \%$ of its electricity from renewables. Almanya elektriğinin $\% 27$ 'sini yenilebilir kaynaklardan üretmektedir. (BT: Germany generates $27 \%$ of its electricity from edible resources.

Of course, the student knows the difference between yenilebilir and yenilenebilir in Turkish, but the syllable - ne is accidentally dropped due to the difficulty in articulating the word, which creates such a humorous interpretation, i.e. that it is possible to eat the resources (wind and solar energy are at issue.). This student is not alone in such articulation, which suggests a phonological difficulty, exacerbated by time pressure (frequency of occurrence: 3 out of 31).

-Syntactic:

Ambiguity and confusion arising from syntactic ambiguity is known to be quite common in English, "given the capacity of the same word to function as a noun, a verb, or something else", depending on the context (Bucaria, 2004, p. 291)

Referential confusion: Such confusion stems from "two possible referents in the sentence" (Bucaria, 2004, p. 296).

The roles/functions of people/things confused and mistaken:

(11) Your memory, alertness, concentration sharpens and we tend to be asleep at 2:00-4:00 am. Sabahları hafızamız, dikkatimiz ve konsantre olmamız daha da kolay, daha da iyi gelişir ve bu da sabahları daha da tatlı bir uyku haline gelmemize sebep olabilir. (BT: Our memory, alertness, concentration sharpens and improves, which may cause us to become a sweet dream.)

The humor in the example (11) arises from the fact we are not transformed into a 
sweet dream, but that it is easier for us to sleep well in the morning. The student is surely aware of this, but seems to have uttered it under time pressure and stress.

Attachment ambiguity: This can be "created by the possibility for a PP (or another type of phrase or clause) to modify one or another component of the sentence/phrase" (Bucaria, 2004, p. 294).

(12) Other cities are paving streets with smog eating concrete and sidewalks with recycled materials. Diğer şehirler beton yiyen dumanlı sokakları ve geri dönüşümlü malzemelerle kaldırımları döşüyorlar. (BT: Other cities are paving smoggy streets which eat concrete and sidewalks with recycled materials.)

In the example (12), streets turn out to be smoggy and eat concrete due to improperly attaching the phrase (with smog eating concrete), i.e. the students failed to perceive 'smog eating concrete' as an indivisible unit of meaning, making the resultant utterance surrealistic and humorous.

Word order: Literal translation may result in placing a phrase wrongly in the sentence (Farghal, 2006). This may lead to a humorous script.

(13) Floyd was 46 years old when the police handcuffed and pinned him down, after according to officers he physically resisted.-Floyd, resmi ifadelere göre, polise karşı resmen direnç gösterdikten sonra, polis onu yakalayıp, ellerini kelepçeleyip, yere koyduğunda 46 yaşındaydı. (BT makes no contribution to understanding for this category.)

The amusing conclusion we reach in interpreting is that there is a relation between his physical position and his age, 46 , in other words, at the very moment that he was put into that position, he turned 46 . This erroneous interpreting results from the literal translation due to inflexible attitude to the reproduction of the structure of wh-clause (frequency of occurrence: 3 out of 8).

-Stylistic:

Coherence: "Coherence consists of the arrangement and sequencing of the concepts and relations of the textual world, which underlie and are realized by the surface text" (Hadla, 2015, p. 179). 
(14) You can become immune by getting sick or getting a vaccine. Bağışıklık sisteminizle ya hasta oluyorsunuz ya da aşıya karşı dirençli oluyorsunuz. (BT: With your immune system, you either get sick or you become resistant to the vaccine.)

In the example (14), vaccines make us resistant to diseases, but the interpretation suggests that with our immune system, we become resistant to vaccines. This accidental humor arises from the reversal of cause and effect, that is, in the source utterance, it is by getting sick or getting vaccined that we become immune, but in the interpretation, surprisingly, the situation is reversed. The student knows this, yet, may have uttered it under time pressure and stress.

-Linguistic confusion:

This occurs especially during a liaison interpreting, due to confusion about or forgetting into which language one is supposed to interpret, and erroneously speaking in the source language. This was found as a new category in the study.

The typical situation appears when liaison interpreting takes place, where the interpreter is interpreting for both parties, and using the two languages successively, to maintain the interaction. In such an atmosphere, students may, by mistake, use English while turning to the non-English speaking party, and vice versa, forgetting to interpret the oral text. There are many such incidents each year, and our corpus is no exception. It affects some students more than others. This might arise from the codeswitch in notes, as well as stress caused by increased cognitive load. Such error does not create much confusion if the students are among their bilingual classmates, but when the trainee interpreter speaks in English after listening to a guest who speaks only English, the situation becomes humorous as the speaker exhibits confusion through their body language and gesture, and the interpreting trainee, oblivious of the mistake, is a humorous sight for the audience, in our case, the trainee's peers.

-Numerical confusion: A numerical confusion is not a rarity in interpreting classes, as numbers are known to be problematic for foreign language learners, interpreters being no exception. However, such confusion becomes humorous in interpreting when confusion of the numbers/years in the ST reaches the point of absurdity. This was found as a new category in the study. 
(15) Ibn Khaldun, famous historian, philosopher, politician and a sociologist, was born on May 27, 1332 in Tunisia.

In the example (15), the interpreting trainee interpreted the birth year of Khaldun, 1332, into Turkish as 1932, which dramatically changed the time scale and accidentally made him a contemporary figure, which caused humor. The reason may be attributable to two reasons: The first one is exclusive to Turkish learners of English. As XenidouDervou, a lecturer on mathematical cognition, stated, "even small difficulties caused by the number naming system could potentially be an additive hurdle to everyday mathematical skills", as cited in Jagatia (2019). The processing in Turkish year numbering is based on enunciating each digit, as opposed to English for which the usual way is to enunciate the first two digits together as one number, and the second two together as another. Thus, Turkish learners of English may have extra difficulty in interpreting dates, echoing the former research on processing of numbers, by Gile (1999), among the others. The second reason may be related to stress, caused by the need to focus simultaneously on dates and the associated details while interpreting. The final reason may be the numbers' having lower informativity than words, as stated by Wu \& Wang (2009, p. 402).

\section{Discussion}

The current study detected 38 different verbal instances of accidental humor. (See Attachment for the whole list of instances). Apart from the established verbal resources of accidental humor, the study included new groups and subgroups as follows: collocational confusion, interlingual homograph and homophone, syllable omission, linguistic confusion, and numerical confusion. These may be claimed to be exclusive to interpreting context, as all stem from confusion either in note-taking in preinterpretation, or during the interpreting process.

The findings highlight that, in some of the instances, accidental humor arises from the accidental alteration of the original meaning to the point of meaninglessness or absurdity, complying with the findings by Macharia (2019).

Our corpus is collected from the context of consecutive interpreting. We had, therefore, better start with the two most frequent causes of mistakes, cited by the students, namely, nervousness and stage fright, and as an introspective view, give a 
warning about these. Nervousness, which is articulated as a reason for errors by almost every interpreting trainee throughout the semester, and peaks at the exams, could not be regarded as the major or sole reason, because no matter how nervous, some students are never seen to make an error of a certain type, for instance, semantic ambiguity, in cases where they have a command on the semantic field of the particular lexical item, and otherwise would make such error anytime, anywhere, irrespective of the nervousness factor. In the majority of the instances, the voice recordings for the assigned consecutive interpreting tasks are sent directly to the lecturer. This suggests that the stage fright cannot be a fundamental reason for such accidentally humorous incidents, as the recordings are made individually at home, where the student would feel relatively more relaxed. So, the presence of accidental humor instances in these home-produced interpretations offer further proof that stage fright is not to be the main reason, at least for the majority, as these were recorded at home, without an audience of peers. However, as in real life, the consecutive interpreting task is fulfilled in an extremely limited time, which complicates matters for the students, thus, time pressure and the resultant stress, inevitable components of consecutive interpreting, might be a catalyst of such errors. Indeed, out of 38 verbal instances, only 6 were seen during in-class activities. The rest occurred during the exams, which confirm the role of stress and time pressure in triggering such accidentally humorous occurrences. As it is known, there is a tendency to spend the minimum cognitive effort under stress and time pressure, in particular when the exams are concerned. (See Attachment for the relevant distribution.)

Fatigue due to the length of text, which is known to increase the cognitive load in the interpreting process, cannot be held accountable in our case, because the length of texts and duration of interpreting were strictly controlled.

Another follow-up reason may be traceable to division of attention between multiple concurrent operations, resulting in overloaded working memory, as specified in the Effort Models by Gile (1995). The more informative the speech sections, the harder the processing, retention and interpretation of information. So, some students, especially with weaker reading and listening skills, must have experienced some difficulty in implementing all of these operations under stress and time pressure. In addition, an underlying reason may be the principle of brevity, a strategy, which interpreting trainees may (un)consciously apply to enable minimal effort in text comprehension and production, which tends to cause the students to simplify, generalize, abbreviate and omit items (Zheng, 2014). The accidental humor instances in this study which may 
possibly be resulting from this principle are in instances(s) of Redundancy, morphophonological, phonological, syntactic resources and syllable omission. The common point in such instances is that interpreting trainees may have (un)consciously taken a literal approach as well as likened the verbal units to the morpho- and/or phonologically similar units to expend the minimum effort, that is, they would need more effort if they more carefully processed the sentences with a more complicated syntax, by avoiding the literal approach, or if they used a more appropriate word than simply using the interlingually homographic or homophonic word.

After specifying some possible psychological and cognitive reasons, let us now specify some possible linguistic reasons. In particular, Farghal (2006) attributes the accidental humor to linguistic incompetence, within the context of his own corpus; however, this attribution is less valid when it comes to the corpus of this study collected from the interpreters-to-be, who can be considered to be a highly language-conscious group, as well as having relatively higher levels of linguistic skill. However, most of the accidental humor instances are found in the morpho-phonological resources (9 instances) and followed by coherence related instances (7) and attachment ambiguity (5). The first category is traceable to insufficient lexical and pronunciation knowledge and momentary confusion, and the other two, to insufficient grammatical and contextual knowledge. The majority of the instances'being collected from the exams suggest that the student failed to make an adequate search about the context and the related terminology.

For the purposes of this qualitative study, some instances, though few, were obtained from a student during the class activities. This was upon the initiation by the instructor, and involved only one or two students interpreting the texts aloud, unlike the texts in exams, where the whole population's interpretations were recorded and analyzed. However, some implications may be suggested at this point to highlight some preliminary explorations: The same accidental humor units marked by underlined words was seen only in a handful of instances in linguistic resources; the frequency of occurrence, was seen most in Lexical ambiguity ( 5 out of 31 in instance 1 ) followed by Syllable omission ( 3 out of 31 , in instance 1 ) and Word order ( 3 out of 8 in instance 1), and Morphophonological similarity ( 3 out of 31, in instance 5; 2 each out of 31 in instances 6 and 7 (See Attachment for instances). As it is seen, the frequency of such occurrence is statistically insignificant to reach any conclusions about the difficulties about those specific words/terms, but it is evident from the classification that the instances in Syllabus omission and 
Morphophonological similarity might not appear if the students translated (not interpreted) those words, as those errors might well be related to misunderstanding, phonological confusion, or mispronunciation.

Some instances may be more generally found across all students'interpretation, as in numerical confusion, while for other instances, some individuals may be more prone than other, a fact which shows the personal, cognitive aspect. These mistakes may be inevitable for some students due to momentary confusion e.g. certain students may be prone to linguistic confusion in the interpretation for no apparent good reason. Individual differences may be explained by various reasons, both positive, such as the student's advanced level of both working languages, and negative, such as highly felt cognitive pressure and nervousness. An example of the latter is spoonerism, from which only a small proportion of students seem to suffer.

The other causes of accidental humor may prove not to be peculiar to interpreting, but equally apply to translation are in compliance with the linguistic and translational literature. These are related to interaction between language and culture, linguacultural sensitivities, translational norms, metalinguistic dimension of scripts (Al-Kharabsheh, 2008), and instant traps such as "cross-linguistic overlap in semantics, orthography, and phonology" (Lemhöfer \& Dijkstra, 2004, p.533), misunderstandings triggered by the interlocutors, interpreters, and the setting (Yetkin-Karakoç, 2015), inaccuracy, mistake/flaws in different linguistic components (Macharia, 2019, p. 2).

Unlike intentional humor, regarding the instances seen during the in-class consecutive interpretation activities, trainees were, unsurprisingly, totally oblivious of the humor in their interpretation. They understood that there was something wrong only when classmates indicated (either physically, by laughing, or through emojis), or when prompted later by the instructor. However, they did not feel the embarrassment they would have felt had no humor occurred. On the contrary, when in class, most enjoyed the humor along with their classmates, or, with voice recording, when the instructor made them aware of the joke. This is because humor, whether intentional or unintentional, had some positive results. It introduced a friendlier atmosphere and strengthened the social relations, as in Farghal (2006). To clarify matters, unlike intentional disparaging humor, such humor tends to produce sense of sympathy towards the interpreting trainee, and our examples revealed that peers even showed gratitude for the lighthearted relief provided. 
In a stressful atmosphere of a consecutive interpreting class, where a trainee cannot predict the speaker's next word or utterance, such accidental humor, though relatively uncommon compared to other mistakes, reduced classmates' anxiety and relieved stress, as stated in Consalvo (1989). Besides, all the functions of humor discussed in literature review contribute to the efficiency of an interpreting class, bringing a breath of fresh air and memorable occasions, and leading to practical, creative interpreting solutions, and an atmosphere conducive to interpreting.

A byproduct of the classification of accidental humor instances through the data obtained in this study may be that it may be of value in the theoretical part of the consecutive interpreting courses to enable the students to grow awareness of the possible difficulties along with the resultant errors they might cause in the interpreting process. Ultimately, as in any other classification, such classification can help students and instructors understand the points to be improved during learning and teaching process. As a result, such classification might indicate items to be included as part of remedial teaching/learning, by exploiting the incorrect forms produced by the learner, in a controlled manner, as highlighted by the seminal work by Corder (1973). The humorous instances in this corpus to be enriched by other instances form other classes would create a positive and light-hearted atmosphere, which would facilitate the discussion of errors. Thanks to the classification, the interpreting trainees may see how multilayered and challenging language is, as a tool, and how the interpreting process doubles the complexity by involving two languages. They would understand how the mind hastens to fill any gap, caused by the shortfalls in the processing capacity under psychological, cognitive, and linguistic constraints, and may develop strategies for avoiding errors, where possible, and otherwise, for coming to terms with them. For instance, they may come to understand that some syllable omissions or numerical confusions might be inevitable due to their inherent features, but some syntactic errors might well be preventable, with improvement in their working languages for interpreting. In a nutshell, these instances might prove to be a set of linguistic food for thought in the curriculum, valuable at the beginning of the course for growing awareness in trainees, and practically whenever further instances emerge for corrective action.

\section{Conclusion}

The present paper has analyzed verbal resources of accidental humor in a corpus of utterances interpreted from English into Turkish in a consecutive class setting. The 
main categories, including lexical, morphological and morpho-phonological and syntactic were further subdivided, and illustrated with examples. There are categories previously encountered, as well as those discovered in this paper: collocation confusion, interlingual homograph and homophone, syllable omission, linguistic confusion and numerical confusion. The detected items are by no means exhaustive, as also stated by the former studies, but enables greater understanding about the types and possible causes of accidental humor which may occur during the interpreting process. The origins of categories are many and varied. They may be cognitive, psychological, misunderstanding, personal-based, or instantaneous, which suggests that the current categorization is far from complete.

The study not only highlighted the possible linguistic resources and possible reasons of accidental humor in the consecutive class, but it also highlighted the pedagogical effects of such humor, because it led to benefits, among which were strengthening the existing friendly ties among classmates and relieving the stress which inevitably accompanies the interpreting atmosphere. The classification of verbal resources of accidentally humorous instances offered in the study not only gives an insight for linguistics but also may be used as part of remedial teaching/learning in the curriculum of interpreting courses.

For future studies, verbal resources may be examined in the simultaneous interpreting context. The linguistic and personal causes may be further investigated by in-depth interviews immediately after the classes where such instances occurred, to collect more detailed cognitive and psychological data, enabling the instructors to gain further insight into such phenomena. Additionally, the nonverbal resources of accidental humor may be examined in a post-pandemic period in a face-to-face training period, highlighting the relative contribution of universal, cultural, and context-based aspects.

Peer-review: Externally peer-reviewed.

Conflict of Interest: The author has no conflict of interest to declare.

Grant Support: The author declared that this study has received no financial support.

Hakem Değerlendirmesi: Dış bağımsız.

Çıkar Çatışması: Yazar çıkar çatışması bildirmemiştir.

Finansal Destek: Yazar bu çalışma için finansal destek almadığını beyan etmiştir. 


\section{References}

Agbedo, C. U., \& Krisagebedo, E. C. (2014). 'My Oga at the top': Pragmatic failures in the Nigerian inter-lingual communication context and the linguistic mechanism of accidental humor. Innovare Journal of Social Sciences, 2(4), 28-34.

Ageli, N. (2014). For better or for worse: The challenges of translating English humour into Arabic. Journal of Human Science, 23, 414-426. Retrieved from https://journal.uob.edu.bh/bitstream/handle/123456789/1229/ JHS20140209. pdf?sequence $=1$

Al-Kharabsheh, A. (2008). Unintentional humour in the translation of Jordanian shop signs. Journal of Intercultural Communication, 17, 1-21. Retrieved from http://www.immi.se/intercultural/nr17/kharabsheh. pdf

Askildson, L. (2005). Effects of humor in the language classroom: Humor as a pedagogical tool in theory and practice. Arizona Working Papers in SLAT, 12(1), 45-61.

Attardo, S., \& Raskin, V. (1991). Script theory revis(it)ed: Joke similarity and joke representation model. Humor: International Journal of Humor Research, 4(3/4), 293-347. https://doi.org/10.1515/humr.1991.4.3-4.293

Bainum, C, Lounsleury, K., \& Pollio, H.R. (1984). The development of laughing and smiling in nursery school and children. Child Development, 55, 1946-1957. doi:10.1111/J.1467-8624.1984.TB00436.X

Beckett, S. (1953). Watt. Paris: The Olimpia Press.

Brône, G. (2008). Hyper- and misunderstanding in interactional humor. Journal of Pragmatics, 40 (12), 2027-2061. doi: 10.1016/j.pragma.2008.04.011

Bucaria, C. (2004). Lexical and syntactic ambiguity as a source of humor: The case of newspaper headlines. Humor-International Journal of Humor Research, 17(3), 279-310.

Consalvo, C. (1989). Humor in management: No laughing matter. Humor: International Journal of Humor Research, 2, 285-297. https://doi.org/10.1515/humr.1989.2.3.285

Corder, S.P. (1973). Introducing Applied Linguistics. Middlesex: Penguin.

Court. (2021, 25 February). In Merriam Webster. Retrieved from https://www.merriam-webster.com/dictionary/ court\#: :text=(Entry\%201\%20of\%202),king\%20held\%20a\%20general\%20court.

Cousins, N. (1991). Anatomy of an illness as perceived by the patient. New York: Bantam.

Critchley, S. (2002). On humour. London \& New York: Routledge.

Deneire, M. (1995). Humor and foreign language teaching. Humor: International Journal of Humor Research, 8(3), 285-298. https://doi.org/10.1515/humr.1995.8.3.285

Dijkstra, T., Grainer, J., \& van Heuven, Walter J. B. (1999). Recognition of cognates and interlingual homographs: The neglected role of phonology. Journal of Memory and Language, 41, 496-518. Retrieved from https:// www.andrew.cmu.edu/user/natashat/bilingualism/dijkstra.pdf

Farghal, M. (2006). Accidental humor in international public notices displayed in English. Journal of International Communication, 12(2). Retrieved from http://immi.se/intercultural/nr12/farghal.html. 
Freud, S. (2003). Espriler ve bilinçdışı ile ilişkileri. Freud Kitaplığı 7. (E. Kapkın, Trans.), (4.Ed.). İstanbul: Payel Kitabevi. (Original work published 1905).

Garner, R. (2004). Humor in pedagogy: How HA Ha can lead to AHa! College Teaching, 54(1), 177-180. https://doi. org/10.3200/CTCH.54.1.177-180

Gile, D. (1995). Basic Concepts and Models for Interpreter and Translator Training. Amsterdam: John Benjamins.

Gile, D. (1999). Testing the effort models' tightrope hypothesis in simultaneous interpreting: a contribution. Hermes 23, 153-172.

Grice, H. P. (1975). Logic and conversation. In P. Cole \& J. Morgan (Ed.), Syntax and Semantics, Speech Acts 3 (pp.4158). New York: Academic Pres.

Hadla, S. L. (2015). Coherence in translation. Research on Humanities and Social Sciences, 5(5), 178-185. www.iiste. org ISSN (Paper)2224-5766 ISSN (Online)

Holmes, J., \& Marra, M. (2006). Humor and leadership style. Humor, 19(2), 119-138. doi:10.1515/HUMOR.2006.006 Ibraheem, S. D., \& Abbas, N.F. (2016a). Pun and (un)intentional humor. Journal of American Academic Research. Retrieved from https://asels.org/wp-content/themes/asels/uploads/12867_5c4f64b05722b.pdf.

Ibraheem, S. D., \& Abbas, N.F. (2016b). A pragmatic study of humor. Advances in Language and Literary Studies, $7(1), 80-87$.

Jagatia, A. (2019, November). Why you might be counting in the wrong language. BBC Future. Retrieved from https://www.bbc.com/future/article/20191121-why-you-might-be-counting-in-the-wrong-language Lemhöfer, K., \& Dijkstra, T. (2004). Recognizing cognates and interlingual homographs: Effects of code similarity in language-specific and generalized lexical decision. Memory \& Cognition, 32(4), 533-550.

MacHovec, F. J. (2012). Humor- Theory, History, Applications. Bloomington: iUniverse, Ic.

Macharia, D. M. (2019). A linguistic analysis of translation errors on selected public notices in Kenya. Editon Cons. J. Lit. Linguist. Stud. (1),1-12. doi: https://doi.org/10.51317/ecjlls.v1i1.54

Morreall, J. (1983). Taking laughter seriously. Albany, NY: State University of New York.

Nijholt, A. (2015). The humor continuum: From text to smart environments (keynote paper). In Proceedings International Conference on Informatics, Electronics \& Vision (ICIEV) (pp. 1-10). Fukuoka: IEEE Xplore.

Nilsen, A. P., \& Nilsen, D. L. F. (2000). Encyclopedia of 20th-Century American humor. Phoenix: Oryx Press.

Oaks, D. D. (1994). Creating structural ambiguities in humor: Getting English grammar to cooperate. Humor: International Journal of Humor Research, 7(4), 377-401.

Pavlicek, M., \& Pöchhacker, F. (2002). Humour in simultaneous conference interpreting. The Translator, 8(2), 385400. doi: 10.1080/13556509.2002.10799139.

Pöchhacker, F. (1993). This isn't funny. A note on jokes in simultaneous interpreting. In C. Picken (Ed.), Proceedings of the XIIIth World Congress of FIT. Vol. 1 (pp. 455-464). London: Institute of Translation and Interpreting.

Raphaelson-West, D. (1989). On the feasibility and strategies of translating humor. META XXXIV(1), 128-141. doi:https://doi.org/10.7202/003913ar

Raskin, V (1985). Semantic mechanisms of humor. Boston: D. Reidel. 
Rishel, M, A. (2002). Writing humor: Creativity and the comic mind. Detroit, MI: Wayne State University Press.

Ross, B. (1992). That's a good one! Corporate leadership with humor. San Marcos, CA: Avant Books.

Ruch, W, Platt, T, Proyer, R. T., \& Chen, H-C. (2019). Editorial: Humor and laughter, playfulness and cheerfulness: Upsides and downsides to a life of lightness. Frontiers in Psychology. 10: 730. doi:10.3389/fpsyg.2019.00730.

Sabato, G. (2019, June). What is so funny? The science of why we laugh. Scientific American, Retrieved from https://www.scientificamerican.com/article/whats-so-funny-the-science-of-why-we-laugh/

Sellers, N. (2018). Spoonerisms: An analysis of language processing in light of neurobiology. All Regis University Theses. 896. https://epublications.regis.edu/theses/896

Shah, H., \& Warwick, K. (2017). Machine Humour: Examples from Turing test experiments. Al \& Soc 32, $553-561$. https://doi.org/10.1007/s00146-016-0669-0

Stephenson, R. (1951). Conflict and control functions of humor. American Journal of Sociology, 56(6), 569-574. Retrieved from http://www.jstor.org/stable/2772475

Straus, I. J. (2014). Incongruity theory and the explanatory limits of reason. UVM Honors College Senior Theses. 26. https://scholarworks.uvm.edu/hcoltheses/26

Viaggio, S. (1996). The pitfalls of metalingual use in simultaneous interpreting, The Translator, 2(2), $179-98$. https://doi.org/10.1080/13556509.1996.10798973

Vymětalová, D. (2017). Strategies of interpreting humour in the European Parliament (Master's Thesis, Palacky University Olomouc). Retrieved from https://theses.cz/id/3971eo/Vymetalova_Daniela_DP.pdf

Wu, G. \& Wang, K. (2009). Consecutive interpretation: A discourse approach. Towards a Revision of Gile's Effort Model. Meta, 54(3), 401-416. https://doi.org/10.7202/038305ar

Yetkin-Karakoç, N. (2015). Analyzing misunderstanding in consecutive interpreting in sensitive settings and interpreter training. Edebiyat Fakültesi Dergisi, 32(1), 277-288.

Zheng, W. (2014). The principle of brevity in simultaneous interpreting. In Proceedings 2nd International Conference on Education, Management and Social Science (ICEMSS 2014) (pp. 136-138) Atlantis: Atlantis Press.

Zillmann, D., \& Stocking, S. H. (1976). Putdown humor. Journal of Communication, 26(3), 154-163. https://doi. org/10.1111/j.1460-2466.1976.tb01919.x

Ziv, A. (1988). The influence of humorous atmosphere on divergent thinking. Contemporary Educational Psychology, 8, 68-75. https://doi.org/10.1016/0361-476X(83)90035-8 


\section{Attachment}

Lexical ambiguity

1. How do they (vaccines) work? Aşılar nasıl çalışırlar? (BT: S.Jackson accused him as my twin on instagram.) (excerpted from an in-class activity, frequency of occurrence:5)

2. Just before he was six, his father took Mozart to Munich to play at the court. Daha 6 yaşına gelmeden babası mahkemede çalması için onu Münih'e götürdü. (BT:When one sneeze gets into your body, your immune system is affected from it.) (excerpted from an in-class activity)

Semantic overlap

1. All it takes is one sneeze for a virus to get into your body. Bir hapşuruk vücudunuza girdiğinde bağışıklık sisteminiz bundan etkilenir. (BT:When one sneeze gets into your body, your immune system is affected from it.) (excerpted from an exam recording)

2. S. Jackson called him on instagram as his twin -S.Jackson instagramında kendisini ikiz kardeşim diye itham etmiştir. (BT: S.Jackson accused him as my twin on instagram.) (excerpted from an exam recording)

Collocational confusion

1. We can cut the world's yearly carbon emissions by a third. Ağaçları kesmemiz karbon emilimini hızlandırır. (BT: Our cutting the trees accelerates the carbon absorption.) (excerpted from an exam recording)

\section{Redundancy}

1. New innovations are making important strides possible. Yeni yenilikler imkansızı gerçek kılıyor. (BT: N/A.) (excerpted from an exam recording)

\section{Morpho-phonological}

1. Egyptians applied kohl all around their eye. Kohl might have helped Egypt ward off infectious diseases. Mısırlılar gözlerinin çevresine sürme çektiler. Bilim insanları kömür sürmelerinin bulaşıcı hastalıklarla savaşmalarında yardımcı olduğunu düşünüyor. (BT: Egyptians applied kohl all around their eye. Scientists believe that their application of coal might help them struggle against infectious diseases.) (excerpted from an in-class activity) 
2. How you treat people is important in interpersonal communication. The word treat here was pronunced as threat, as a result of which a student interpreted as follows: İnsanları nasıl tehdit ettiğiniz kişilerarası iletişimde önemlidir. (BT: How you threaten people is important in interpersonal communication.) (excerpted from an in-class activity)

3. The main regulator of circa diem can be found in hypothalamus, a small area at the base of your brain. Sirkadiyen döngünün ana regülatörü beynin arkasında bulunur, tıpkı hipopotamlardaki gibi. (BT: The main regulator of circa diem is found at the base of your brain, like in hypopothamuses.) (excerpted from an exam recording)

4. The Circadian rhythms affect three big necessities-eating, sleeping and mating. - Sirkadyen ritimler 3 büyük gereksinimi etkiler: yeme, uyuma, vakit geçirme. (BT: Circadian ryhthms influence the three big needs: eating, sleeping, spending time.) (excerpted from an exam recording)

5. Get rid of the fatty foods! Yağlı yiyeceklere hazır olun! (BT: Get ready for the oily food!) (excerpted from an exam recording, token:3)

6. A new public building in Mexico City has an exterior that breaks down air pollutants, erasing the effects of 1000 cars each day. Mexico City'de yeni bir kamu binası havayı kirleten maddeleri parçalayan bir dış cepheye sahip ve 1000 arabanın bu etkisiyle yarışıyor. (BT: A new public building in Mexico City has an exterior that breaks down air pollutants, racing with 1000 cars to produce such effect.) (excerpted from an exam recording, the frequency of occurrence: 2)

7. Paris installed street tiles that harvest energy from foot traffic. Paris ise yemek kamyonlarından enerji üretmektedir. (BT: Paris produces energy from food trucks.) (excerpted from an exam recording)

8. When your immune system sees the infection, it makes special proteins called antibodies that stick to the surface of the virus, that makes it easier for the white blood cells to find and destroy. Bazı proteinler kana karışır. Böylece hasta oluyorsunuz, o zaman antibiyotik kullanılıyor. (BT: some proteins get into the blood. Therefore you become sick, then one uses antibiotics.) (excerpted from an exam recording)

9. The viruses are always killed or weakened before it is getting into you. Virüsler size verilmeden önce her zaman öldürülür ve haftasonu enfeksiyon. (BT: Before the viruses get into you, the viruses are always killed and at the weekend, there is infection) (excerpted from an exam recording) 
Phonological

Interlingual homograph

1. Sembolizm akımının etkileri şiir ve romanda görüldü. The influences of the symbolism movement was seen in poem and roman (excerpted from an in-class activity)

Interlingual homophone

1. More (innovations) are on the way. We will take a shared sense of urgency from countries, companies, cities and all of us working together. Dünyamız yeniliklere açmak gelecekte birazcık acil durum niyetine girecek. Ülkelerden, şirketlerden, sitelerden bunu bekliyor, birbirimizle beraber çalışmamızı bekliyor. (excerpted from an exam recording)

Spoonerism

1. Bu akımın temsilcileri arasında Yahya Kemal ve Tevfik Fikret vardır.-The representative of this movement include Yahya Kemal and Tevfit Fitret (BT: See the switch in letters) (excerpted from an in-class activity)

Syllable omission

1. Germany generates $27 \%$ of its electricity from renewables ...Almanya elektriğinin $\% 27$ 'sini yenilebilir kaynaklardan üretmektedir. (BT: Germany generates 27\% of its electricity from edible resources.) (excerpted from an exam recording, token:3)

Syntactic

Roles/functions confused

1. His boss (S.Jackson's boss) said his employers loved him.-Çalışanları onu çok severdi. (BT: His employees loved him.) (excerpted from an exam recording)

2. It turns out that you are not just lazy.-Bunun nedeni vücudunuzun tembel olması değil (BT: it is not that your body is lazy.) (excerpted from an exam recording)

3. Your memory, alertness, concentration sharpens and we tend to be sleep at 2:00-4:00 am. Sabahları hafızamız, dikkatimiz ve konsantre olmamı daha da kolay, daha da iyi gelişir ve bu da sabahları daha da tatlı bir uyku haline gelmemize sebep olabilir.(BT: Our memory, alertness, concentration sharpens and improves, which may cause us to become a sweet dream.) (excerpted from an exam recording) 
4. If every American drove 10 miles less each week it could eliminate more than a hundred billion pounds of carbon from the air. Her araç 10 mil daha az sürse, yüz milyar kadar enerjiye kavuşuruz.(BT: If every car drove 10 miles less, we would gain about 100 billions of energy.) (excerpted from an exam recording)

Attachment ambiguity

1. Your body has an internal biological clock that has its own plans in mind.-Biyolojik saatiniz ve aklı olan vücudunuz kendi planını yapmakta özgürdür. (BT: your biological clock and your body with a mind of its own adjust itself freely) (excerpted from an exam recording)

2. You are much more likely to suffer from an accidental poisoning, get in a car crash, get struck by a lightning than you are to be harmed by a vaccine. Bir araba kazasından ötürü zehirlenmeniz veya yıldırımdan ötürü zehirlenmeniz çok daha yüksek olasılıktır (BT: You are much more likely to suffer from poisoning due to a car crash, or a lightning (than you are to be harmed by a vaccine) (excerpted from an exam recording)

3. Living the night life mess you up, leaving you exhausted, confused and sick. Geceleri hayatı yaşamak sizi yorar, mahveder hatta hasta eder. (BT: leading the life at night leaves you exhausted, messed up and even sick.) (excerpted from an exam activity)

4. Other cities are paving streets with smog eating concrete and sidewalks with recycled materials. Diğer şehirler beton yiyen dumanlı sokakları ve geri dönüşümlü malzemelerle kaldırımları döşüyorlar.(BT: Other cities are paving smoggy streets which eat concrete and sidewalks with recycled materials.) (excerpted from an exam recording)

5. If we embrace solar and wind power to their full potential, we can cut the world's yearly carbon emissions by third. Already Germany generates $27 \%$ of electricity from renewables. Zaten dünyanın üçte birini satın alan Almanya, elektriğinin \%27'sini yenilenebilir kaynaklardan üretmektedir. (BT: interpretation missing until by third. Germany already having bought one third of the world, generates $27 \%$ of electricity from renewables.) (excerpted from an exam recording)

\section{Word order}

1. Floyd was 46 years old when the police handcuffed and pinned him down, after according to officers he physically resisted.-Floyd, resmi ifadelere göre, polise karşı resmen direnç gösterdikten sonra, polis onu yakalayıp, ellerini kelepçeleyip, 
yere koyduğunda 46 yaşındaydı. (BT does not help here because the syntax was "literally" translated and the connotation in Turkish cannot be felt by back translation.) (excerpted from an exam recording, the frequency of occurrence:3)

\section{Coherence}

1. You can become immune by getting sick or getting a vaccine. Bağışıklık sisteminizle ya hasta oluyorsunuz ya da aşıya karşı dirençli oluyorsunuz. (BT:With your immune system, you either get sick or you become resistant to the vaccine.) (excerpted from an exam recording)

2. You are much more likely to suffer from an accidental poisoning, get in a car crash, get struck by a lightning than you are to be harmed by a vaccine. Herhangi bir hastalık ya da araba çarpması ya da bir şimşek çarpmasındansa bir aşı daha güvenlidir. (BT: A vaccine is more reliable than an catching an illness, or being involved a a car crash or getting struck by a lightning.) ( excerpted from an exam recording)

3. It (your body system) is synchronized and calibrated according to emergence and disappearance of natural light. Vücut sisteminizin birçoğu doğal ışığın ortaya çıkması ve kaybolması için kalibre edilir. (BT: Most of your body systems are calibrated for the rise and setting of the natural light.) (excerpted from an exam recording)

4. These bacteria and viruses can spread and kill the person before the immune system can fight back. This is where vaccines come in. Virüsler bizim vücudumuzu terkettiğinde aşılar devreye girer, hasta olduğumuzda da. (BT: When the virus leaves our body, the vaccines are at play and when we get sick.) (excerpted from an exam recording)

5. Why is it hard to make your body wake up an hour earlier. or getting adapt to just an entirely different timezone... Your body has an internal alarm clock. Eğer uyanmakta güçlük çekiyorsanız ve eğer gün ışı̆̆ı uyanma güçlüğü yaratıyorsa vücudunuz içsel bir saate sahiptir. (BT: If you have difficulty in waking up or if daylight make it difficult for you to wake up, your body has an internal alarm clock.) (excerpted from an exam recording)

6. In the last two decades, we have experienced 14 of the hottest 15 years on record. By 2050 drought and chronic shortages could impact a billion people...Son 20 yılda 2050ye kadar kaydedilen en sıcak 15 yılın 14ünü yaşadığımız su sıkıntısı çektiğimiz görülmekte.(BT: In the last two decades, we have suffered from chronic shortages in the 14 out of 15 hottest years recorded up until 2050.(excerpted from an exam recording) 
7. He was trying to get by like many Americans who lost their jobs in the worst economic downturn since the Great Depression. Pandemi döneminde maalesef ki diğer birçok Amerikalı gibi işsiz kaldı. Vefat ettiğinde diğer Amerikalılar gibi hayatta kalmaya çalışıyordu. (BT: in the pandemic, he was left unemployed like many other Americans. When he lost his life, he was trying to get by.) (excerpted from an exam recording)

Numerical confusion

1. Ibn Khaldun, famous historian, philosopher, politician and a sociologist, was born on May 27, 1332 in Tunisia. (excerpted from an in-class activity)

2. In the last two decades, we have experienced 14 of the hottest 15 years on record. Son iki asırdır dünyamız 25 yılık bir rekorla çok yüksek sıcaklıkları tecrübe etmiştir. (BT: For the last two centuries, our world has been experiencing the hottest years for a 25 -year record.) (excerpted from an exam recording) 